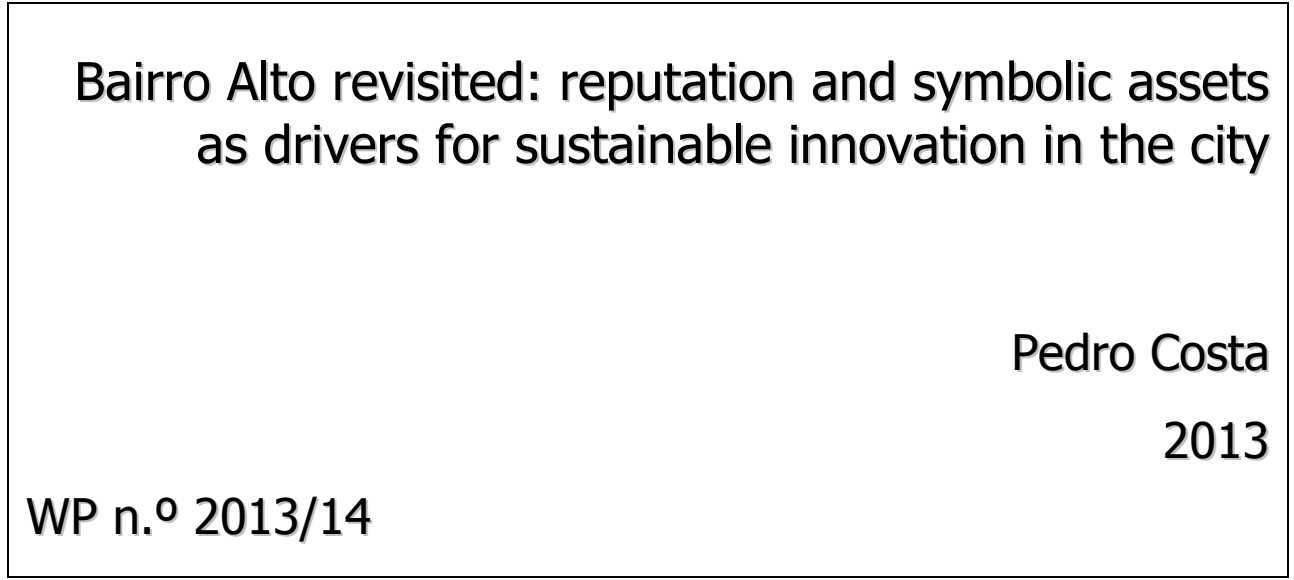

DOCUMENTO DE TRABALHO WORKING PAPER 


\section{DINAMIP'CET}

CENTRO DE ESTUDOS SOBRE A MUDAN
SOCIOECONÓMICA E O TERRITOBIO

ISCTE-IUL

\section{Bairro Alto revisited: reputation and symbolic assets as drivers for sustainable innovation in the city}

Pedro Costa*

WP n. ${ }^{\circ} 2013 / 14$

DOI: 10.7749/dinamiacet-iul.wp.2013.14

1. INTRODUCTION: THE CONDITIONS FOR A REVISITATION OF AN OBJECT OF STUDY.....

2. THE BAIRRO ALTO CREATIVE MILIEU AND THE CHALLENGES TO ITS SUSTAINABILITY.........................5

2.1 The Bairro Alto area: a creative district facing new challenges...................................................................... 5

2.2 Use conflicts, gentrification, territorial dynamics and sustainability of the territorial system ............................. 10

3. THE “DOUBLE LAYER” APPROACH TO THE SUSTAINABLE INNOVATIONS IN BAIRRO ALTO................12

3.1 "Layer A": The "sustainable innovation" projects - Projects for developing innovations for sustainability.............. 12

3.2 "Layer B": A "collective sustainability strategy" - an innovative strategy for the milieu? ..................................... 14

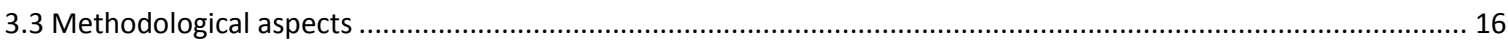

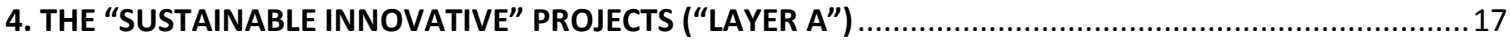

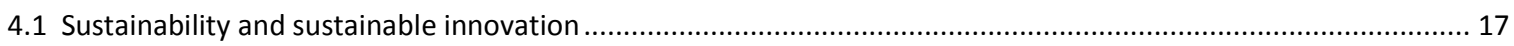

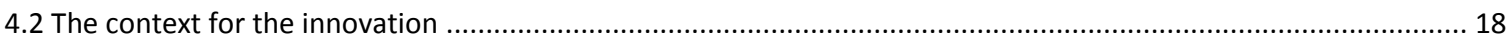

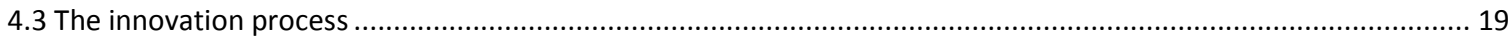

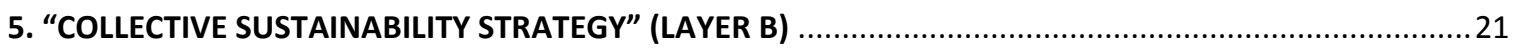

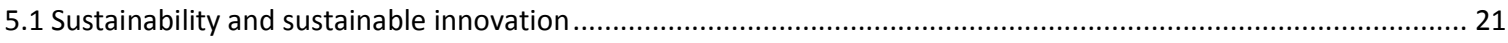

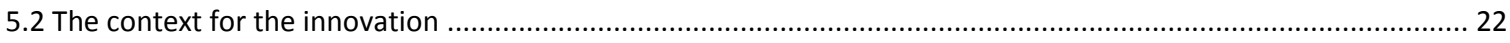

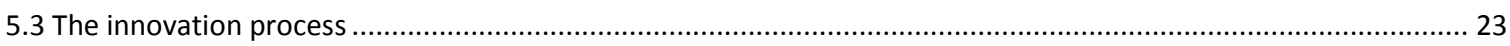

6. REPUTATION BUILDING, GATEKEEPING AND SUSTAINABILITY OF A CREATIVE DISTRICT...................25

7. CONCLUDING NOTE: CHALLENGING THE INNOVATIVE MILIEU? ....................................................27

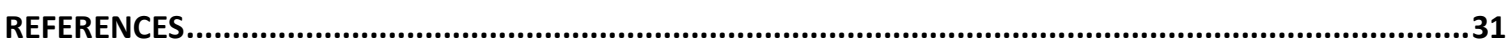

*ISCTE - University Institute of Lisbon (ISCTE-IUL) and DINÂMIA'CET - IUL, Lisbon, Portugal.

Corresponding author: pedro.costa@iscte.pt 


\title{
Bairro Alto revisited: reputation and symbolic assets as drivers for sustainable innovation in the city ${ }^{1}$
}

\begin{abstract}
This text aims to shed some light on the role of sustainable innovation in urban development through the analysis of the case of the cultural and creative district of Bairro Alto, in Lisbon. A double analytical perspective is followed in order to understand the sustainable innovations in the area, and the way they can be mobilized to promote urban vitality and urban sustainable quality of life in city center.

On one hand, a set of "sustainable innovations" which have been developed and introduced in his quarter during recent years with the purpose to develop quality of life of users and residents and minimize use conflicts in the area are studied. These include local projects in fields such as traffic conditioning, graffiti control and public art strategy; urban cleaning systems; or noise control and nightlife schedules management.

On the other hand, the study of a "collective" sustainable innovation, that is linked to the perception of the risks in the evolution of the territorial system and the representations that their agents have about it is developed. Specifically, it relates to the putting in place of a sustainable development strategy for the territory, conducted by some of the local agents, aiming to understand and to deal with the dangers of the overexploitation of this system and the management of its "capacity of charge".

A particular accent is dedicated to the reputation building mechanisms and to the importance of symbolic assets in these processes, challenging the more traditional approaches to urban sustainable development processes and the concept of innovative milieu.
\end{abstract}

\section{Keywords}

Sustainable innovation, cultural districts, urban creativity, reputation, symbolic, Bairro Alto, innovative milieu.

\footnotetext{
${ }^{1}$ This text is developed in the framework of the international research project "Anchoring, Sustainability and Localisation of Innovation: towards new forms of territorialisation of economic activities", funded by PUCA (Plan Urbanisme Construction Architecture), and conducted by a team of GREMI (Groupe de Recherche sur les Milieux Innovateurs) research network. It were assumed the main analytical and methodological frameworks followed on this broader project, which can be consulted on: Kebir, L, P. Costa, O. Crevoisier et V. Peyrache-Gadeau (2012) «Ancrage, durabilite, localisation de I'innovation : vers des nouve lles formes de territorialisation des activites ?» / "Anchoring, Sustainability and Localisation of Innovation: towards new forms of territorialisation of economic activities" (ASLInn), Rapport Final, Recherche menée pour le PUCA - Ministère de l'Ecologie, de l'Energie, du Développement Durable et de la Mer, dans le cadre de la consultation de recherche: « Localisation des activités économiques et développement durable des activités ? », Paris: Octobre 2012.
} 


\section{INTRODUCTION: THE CONDITIONS FOR A REVISITATION OF AN OBJECT OF STUDY}

This text aims to analyze sustainable innovation in the context of an urban creative quarter, the Bairro Alto area, in the city of Lisbon. This is an area which is being through a process of progressive gentrification and massification, like many other cultural quarters in many cities, even if framed in some special characteristic linked to its specific morphology and to its particular evolution (Costa, 2003, 2004; Costa e Lopes, 2012). These processes challenge clearly the sustainability of the area as we know it and the capacity to keep the vitality and creative dynamism that it has been demonstrating through times. The analysis of the cultural/creative production system of the "Bairro Alto" district is thus made in the perspective of identifying the emergence of sustainable innovations in urban development, which were put in place in order to promote urban vitality and to assure quality of life to its users and residents. The dynamics of the production system appear to be strongly linked to the general "ambiance" of the district, and to a set of use conflicts that are marking its evolution and sustainability. The purpose of the case study is to examine some changing issues associated with transformation and innovation in the urban development of the district and how these impact on the localization of cultural and creative activities and practices. A particular attention is dedicated to the symbolic sphere and to the importance of reputation building mechanisms for the image and the own vitality of the territory. The innovations explored stem from local government intervention and/or other forms of coordination and self-regulation of local actors, aimed at creating and maintaining a sustainable and vital territorialized production system. These include a set of projects linked to "sustainable innovation", in fields such as traffic restrictions, the organization of waste collection and sanitary facilities, the noise control, the labeling of products and activities, or the management of street art in public space, for instance. The conflict and the uneven power relations in public space are a key feature in this system organization and are consequently at the center of most of these sustainable innovations. In parallel, an analysis of a collective strategy towards a more sustainable and less over-charging functioning of this territorial system, led by some of its more prominent actors, is also conducted.

The conceptual and empirical work that is now developed draws on some antecedent research, as we have been previously working this area, in several other projects: First, assuming an innovative milieu approach, analysing this territory in the perspective of the cultural resources and their role in the milieu enhancement (in the scope of GREMI6 research program - cf. Costa 2003, 2004). Then, later, focusing on the urban creative dynamics and their governance in the scope of a comparative perspective of international cases of creativity led urban dynamics (the

DINÂMIA'CET - IUL, Centro de Estudos sobre a Mudança Socioeconómica e o Território ISCTE-IUL - Av. das Forças Armadas, 1649-026 Lisboa, PORTUGAL 
CreatCity project - cf. Costa, 2012, 2012a; Costa e Lopes, 2011, 2012). In parallel, the development of other 2 small research projects in this neighbourhood and the organization of two photographic exhibitions about the district, gave the opportunity to never gain too much distance from this object of study, and to be following it in an almost permanent way its evolution.

In effect, after our early in-depth studies in this area, in the late 90's, many things have changed. Many new creative activities have left the Bairro Alto, many other came in. Specific commerce areas, based on high symbolic and aesthetic attributes, have developed. Many hostels and touristic residences have located in the area, fruit of the increase in short-break tourism and of low-cost flight activity in town. Buses full of "more traditional" tourists are every night unloaded in the district entrances, heading to "Casas de Fado" and restaurants. The drug commerce in the streets has seen its peak, and then has become more invisible and discrete again. The residents have mobilized several times against the nightlife problems, as conviviality spots were being increasingly transferred to public spaces outdoors. City council has developed multiple measures to regulate and control all the problems and externalities, trying to manage multiple and conflicting interests, but many times inconsequently or with an unclear and fluctuating path. Public space became increasingly used by institutional and commercial initiatives, most of them with the support of the own city council of main local associations. In parallel, the quarter was fruit of intense informal appropriation by graffiters and street artists, and a huge reaction developed against it. The indiscipline in parking (an old issue between residents and users) and even in the use of streets (e.g, taxis "parking" in the middle of public streets waiting for clients) have grown considerable and so the tensions around it. But most of all, the mainstreaming of the area, even in symbolic terms, made it a growing pole of attractiveness for a broader and much more massified and generalist crowd, looking for the area for commercial, cultural, and mostly convivial motives (special during night time), imposing a much more significant pressure over the territorial system functioning.

The ASLInn project offered the ideal context to in-deep and to update our reflection on this territory, as the conceptual framework of this project, centered on the study of the anchoring and localization issues associated to innovation and to the territorialization of economic activities at the light of sustainable development issues, gave a perfect opportunity to reflect upon the sustainability of this quarter and to research about the development strategy (or absence of it) that the area is assuming, when confronted to real challenges to the continuity of its vitality and facing the excesses in the over-exploitation of resources (related to massification, turistification and gentrification trends in the area) and the increase in the conflicts between its diverse users.

DINÂMIA'CET - IUL, Centro de Estudos sobre a Mudança Socioeconómica e o Território ISCTE-IUL - Av. das Forças Armadas, 1649-026 Lisboa, PORTUGAL 
Before going further, just a brief note on the notion of "sustainability" that is being assumed in this work, which is wide and relatively comprehensive, including the more traditional ecoenvironmental perspective but also a broader sense, associated to the quality of urban life and of urban planning (that is, including what can be covered by the French expression "aménagement $\mathrm{du}$ territoire"), which is essential in the way local actors deal with "sustainability" and "sustainable innovation" issues. Assuming, as in the other case studies of this ASLInn project, a perspective that considers the "sustainable innovations" as the ones recognized as such by the actors involved, we start from a broad departing point at conceptual level, opening the door to urban development issues centred in the urban quality of life and efficient planning practices.

In the following section we will make a brief presentation of Bairro Alto district and the main challenges that it is facing today. On section III, the double layered approach to the sustainable innovation issue is presented and some methodological aspects defined. Section IV and V present the main results achieved in the case study, concerning respectively the diverse "sustainable innovative" projects analyzed and the "collective sustainability strategy" studied in this case. Section VI deals specifically with the reputational issue and the importance of gatekeeping processes in this case, and finally section VII presents a brief concluding note and opens the discussion to the implications these findings present to the innovative milieus approach on sustainable development issues.

\section{THE BAIRRO ALTO CREATIVE MILIEU AND THE CHALLENGES TO ITS SUSTAINABILITY}

\subsection{The Bairro Alto area: a creative district facing new challenges}

The productive system in analysis in this case study - the Bairro Alto area - can be viewed as a cultural and creative activities based Innovative Milieu, as we had opportunity to defend elsewhere (Costa, 2003, 2004, 2007). As such, we can identify in it (i) a specific local production/consumption system, strongly territorially embedded; (ii) a specific governance system, closely linked to a diversity of formal and informal interrelations amongst local agents; and (iii) a specific collective representations system, polarizing strong symbolic aspects in terms of territorial image, both internally and externally (cf. Costa 2003, 2004). It is in close relation and interaction with other close areas of the city (particularly, the contiguous Chiado area ${ }^{2}$, main symbolic and institutional cultural centre of the city in many artistic worlds), and in expansion to other adjacent areas (with some specific activities broadening to Príncipe Real, Bica and Cais

\footnotetext{
${ }^{2}$ Immediately Southeast of the Bairro Alto.

DINÂMIA'CET - IUL, Centro de Estudos sobre a Mudança Socioeconómica e o Território ISCTE-IUL - Av. das Forças Armadas, 1649-026 Lisboa, PORTUGAL Tel. 210464031 - Extensão 293100 E-mail: dinamia@iscte.pt www.dinamiacet.iscte.pt
} 


\section{Reputation and symbolic assets as drivers for sustainable innovation in the city}

do Sodré areas, for instance ${ }^{3}$ - cf Figure 1). At the same time it is in strict articulation with all the metropolitan area, polarizing huge hinterlands in many of the central functions that the area provides (in terms of the cultural and creative activity it provides, sociability practices, nightlife and other cultural consumption practices), being the main and most diversified cultural supply area in the Lisbon metropolitan area. This implies that this relation with the city and wider hinterlands (e.g, the area has affirmed itself as one of the main international tourist destinations within the city, polarizing segments such as short breaks or other) must be seen on a multiscalar perspective, which is essential to understand the functioning and the development of this territorial productive system.

It is not our aim to provide an exhaustive description of this territorial system and its evolution (see Costa, 2003; Costa e Lopes, 2012a; Dias, 2010; Balula, 2010; on this), but just to point briefly some of the main features that give shape to the main challenges that this urban district is facing today, and to the sustainability issues that affect it.

Figure 1: Location of Bairro Alto area

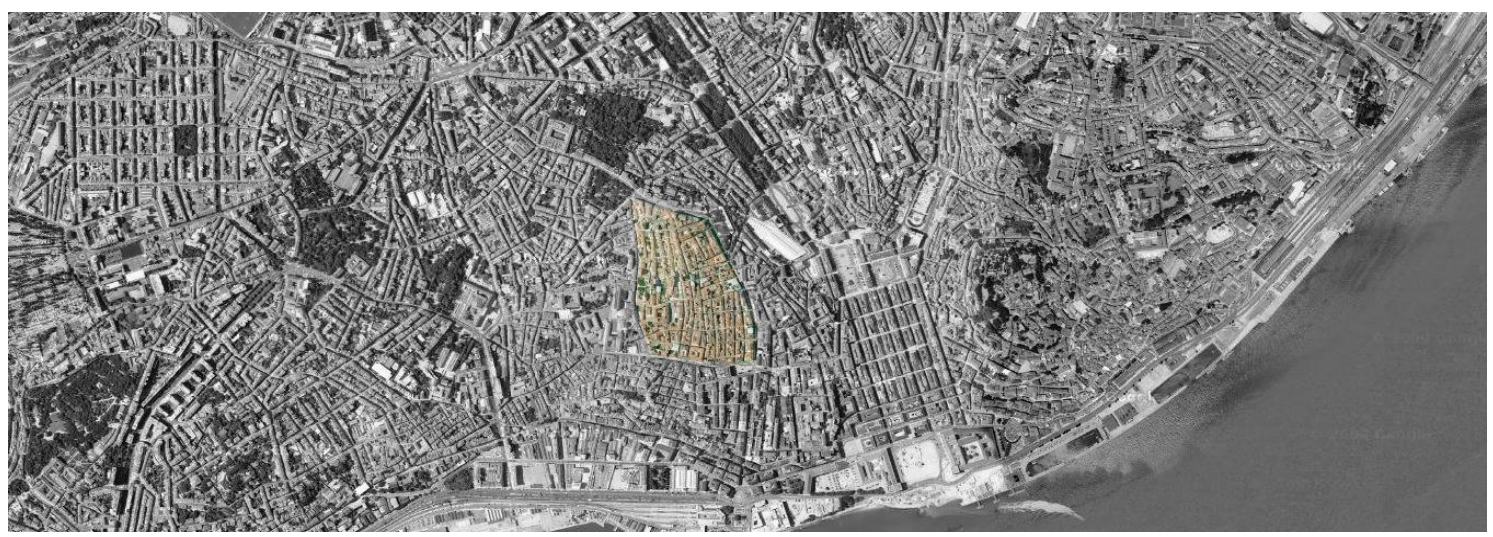

Source: Costa et Lopes, 2012a; own elaboration

The Bairro Alto cultural quarter, located at the old traditional historical center of the city of Lisbon (cf. Figure 1) has its origins in the early XVI century (with the spread out of the walls of the medieval city $^{4}$ ), and since those times it as affirmed itself as the main cultural/creative center of the city, marked by bohemia, creativity and liminality, in a close inter relation with Chiado $\operatorname{area}^{5}$. Despite being considered, during most of XX century, until the 80s, as one of the

\footnotetext{
${ }^{3}$ Príncipe Real area, adjacent to the North/Northwest of Bairro Alto; and Bica and Cais do Sodré, both South of the neighborhood, towards the river Tagus.

${ }^{4}$ The urbanization of Vila Nova de Andrada, corresponding to contemporary Bairro Alto, started in 1513 (Carita, 1994; Dias, 2010).

${ }^{5}$ The "Bairro Alto - Chiado" system studied in Costa (2003), with the more institutional/daytime side Chiado - and the more alternative/transgressive/nighttime area - Bairro Alto - complementing and feeding each other)
}

DINÂMIA'CET - IUL, Centro de Estudos sobre a Mudança Socioeconómica e o Território ISCTE-IUL - Av. das Forças Armadas, 1649-026 Lisboa, PORTUGAL

Tel. 210464031 - Extensão 293100 E-mail: dinamia@iscte.pt www.dinamiacet.iscte.pt 
marginal and poorest districts of Lisbon city center, it kept a particular aura related to alternative and transgressive activities, which developed strongly, more culturally oriented, in the two last decades of the last century. In recent times a geographical expansion of this system (with diversified patterns) is taking place to the closest neighborhoods and other surrounding areas, such as Bica and Cais do Sodré (nightlife and conviviality, performing arts, some alternative activities) or Príncipe Real (antiques, aestheticized consumptions, gay nightlife, etc.).

It is characterized by its density and multiplicity of activities, although they reveal nowadays a changing pattern, evolving from more traditional cultural cluster activities to more consumption oriented "creative sector" activities, but keeping the aura and the ambiance of the cultural/creative district and a huge importance of conviviality and sociability activities (including restaurants and nightlife) ${ }^{6}$. This renewing capacity of the creative quarter through time, from the XVI century, changing the pool of activities that constituted its creative productive system but keeping the sociability mechanisms, the creative and transgressive atmosphere, and the capacity to renew and reinvent its symbolic aura is effectively one of the main features of the area. In recent decades, two main renewing and boosting moments can be identified, one linked to the hype around some alternative activities transversal to diverse cultural fields and nightlife, much related to changes in lifestyles and consumption modes, during the 80 's, and a transformation towards more consumption oriented creative activities and more massified practices of conviviality and socialization during the first decade of XXI century.

All this is happening in an area that is still essentially a residential area with particular morphological conditions, both in terms of built environment (and living conditions) and of public spaces (cf. Carita, 1994; Dias, 2010; Balula, 2010; Costa e Lopes, 2012a), which is determinant in the evolution of the quarter, both in residential and economic terms, as the specific lodging and dwelling conditions and the particular constraints in terms of daily liveliness of the area, make the renewal process extreme selective, attracting specific residents and activities (e.g, temporary residents, or persons with more flexible family models or more hedonistic lifestyle oriented) and orienting and conditioning the gentrification processes. Part of the Florida's "creative class" has here its stage (particularly the most bohemian and artistic oriented), but in a space that is not so attractive to other kind of creative people, and that brings severe complications for a more conventional (income oriented) gentrification process. That

\footnotetext{
${ }^{6}$ E.g amongst many other traditional activities, it was the center of press and printing clusters during second half of $20^{\text {th }}$ century, but now almost all these activities have been de-localized for the outskirts of city, but many other creative and cultural activities (in performing and visual arts, cultural industries, "creative" industries) have took their place, maintaining the ambiance and the livelihood of the district.
} 
does not avoid that the huge quantitative of users that the area polarizes (particularly with nightlife and sociability activities) and the development a wider set of consumption-oriented activities in the area, parallel to a certain symbolic mainstreaming of the area in the public representations and its image, bring severe problems in terms of the diverse conflicts of use amongst the diverse layers of users and residents of the area and in terms of the vast effects of many negative externalities associated to many of these activities. This is an area particularly affected by conflict, in several arenas (public space appropriation, real estate market, symbolic arena,...), as many other cultural quarters around the world (cf. Costa and Lopes, 2012), and that is undoubtedly a structuring feature of the territorial system and its evolution.

Contrary to other similar systems, (direct) public intervention has here essentially a supplementary character, as this vitality is essentially based on endogenous dynamics of the territorial system, with its own governance mechanisms (Costa, 2004, Costa, 2012a). That does not mean that public policies aren't essential to the area evolution, but just that there are no explicit policy to enhance this area as creative quarter, and that would be even undesirable, as of the negative impacts it could cause in symbolic terms and in the capacity of the system to be sustainable (Costa 2007; 2012; 2012a).

With this context in mind, some structural features can be identified, which could be summarized, departing from previous work in this area, around the 6 issues presented on figure 2:

Figure 2: Main structural features of Bairro Alto area

\begin{tabular}{|c|c|}
\hline $\begin{array}{l}\text { - Multiplicity of activities and territorial functions } \\
\text { - Diversity of cultural production and consumption systems } \\
\text { - Permanent evolution and re-composition of the activities }\end{array}$ & $\begin{array}{l}\rightarrow \text { Permanent renovation and re- } \\
\text { invention of the local productive system }\end{array}$ \\
\hline - (Dynamic) Residential area & \multirow{3}{*}{$\begin{array}{l}\text {-> Strong use conflicts } \\
\text { (and importance of externalities) }\end{array}$} \\
\hline $\begin{array}{l}\text { - (Selective) gentrification processes (residents / cultural and } \\
\text { economic activities) }\end{array}$ & \\
\hline $\begin{array}{l}\text { - Important role of conviviality and sociability nodes } \\
\text { (particularly nightlife and bohemia) }\end{array}$ & \\
\hline $\begin{array}{l}\text { - Importance of specific morphological and urban attributes of } \\
\text { space and specific living conditions }\end{array}$ & $\begin{array}{l}\rightarrow \quad \text { Selectivity in transformation } \\
\text { processes }\end{array}$ \\
\hline - Importance of collective representations of the area as creative & $\begin{array}{l}->\text { Symbolic enhancement as creative } \\
\text { area vs mainstreaming risks }\end{array}$ \\
\hline $\begin{array}{l}\text { - Importance of system own governance mechanism and } \\
\text { endogenous dynamics }\end{array}$ & $\begin{array}{l}\text {-> Non-direct / supplementary public } \\
\text { action }\end{array}$ \\
\hline
\end{tabular}

Source: own elaboration. 
The recent evolution of this area (see Costa, 2008; 2012a; Costa and Lopes, 2012a), similar to what occurred in many other cultural quarters around the world, presents new challenges to the renewal capacity of this system, as the pressures to increase gentrification processes, the rise in the internal conflicts, and the risks of massification and turistification are defying the system on a new scale. All these challenges, summarized on the table of Figure 3 make us aware of the need to go further in the inquire of these processes, and to understand the local agents capacity to deal with them, in the management of "sustainable innovative" solutions which could help the economic, social, environmental and cultural sustainability of these area as the main creative quarter of the city. In effect, the challenges to the vitality of this urban area and to its competiveness can be somehow dissociated from the challenges to the maintenance of the creative productive system that has been subsisting on it for centuries (Costa, 2007). And both of them, naturally interlinked, depend on the perceptions, on the will and on the actions of the agents that actually structure that territorial system.

Figure 3. Main recent trends and challenges to the productive system

\begin{tabular}{|c|}
\hline es $->$ in \\
\hline $\begin{array}{l}\text { ii. Substitution of activities and residents -> impact in terms of lifestyles and social and cultural } \\
\text { practices (e.g., public space appropriation; daily neighborhood life;...); possible negative effects in } \\
\text { terms of the liminal aptitudes of the area }\end{array}$ \\
\hline $\begin{array}{l}\text { iii. Shift from "Cultural Production" to " } \\
\text { nightlife take increasingly place of other }\end{array}$ \\
\hline
\end{tabular}

iv. Massification of publics / audiences / users (both in cultural and conviviality activities) -> Overcharge and congestion of the structures; exit (and sometimes self-exclusion) of most alternative and liminal cultural practices

v. Mainstreaming of the area in symbolic terms (both in external and internal representations) -> impacts on social (and economic) re-composition; impacts on the (self-)exclusion of some creative activities

vi. Significant increase in negative externalities (noise, parking, traffic,...) and their impacts -> on one hand, compromising sustainability via decrease in quality of life, but on the other hand, facilitating system reproduction by difficulting gentrification processes

vii. Exit (relative) of part of most creative actors -> expansion and de-location of some "creative" segments to neighborhood areas; potential loosing of scale and milieu effects in their activity

viii. Semi-maintenance of (some) conviviality nodes (even in some art worlds more affected by delocalization to fringe areas) -> potential of keeping some of the key-features of the milieu, linked to socialization (knowledge transfer, collective learning, reputation building,...), which are essential to artistic production/consumption (even without the creation or consumption occurring in this territory)

Source: own elaboration.

DINÂMIA'CET - IUL, Centro de Estudos sobre a Mudança Socioeconómica e o Território ISCTE-IUL - Av. das Forças Armadas, 1649-026 Lisboa, PORTUGAL

Tel. 210464031 - Extensão 293100 E-mail: dinamia@iscte.pt www.dinamiacet.iscte.pt 


\subsection{Use conflicts, gentrification, territorial dynamics and sustainability of the territorial system}

As in many other cultural and creative quarters, conflicts between the several layers of users of these spaces, in several arenas (real estate market, symbolic sphere, public space appropriation), are a fundamental feature of the territorial system and its evolution (cf. Costa and Lopes 2012a). Two main issues assume relevance in this context: on one hand the externalities and other agglomeration effects, associated to the impacts of each activity, that have consequences in other social, economic and cultural practices, and condition their activity and the well-being of users and residents; on the other hand, the gentrification processes occurring in the area, expressing the conflict by the material appropriation of territory.

Regarding gentrification process, it has been naturally developing in this area, although with a diverse pattern than other areas, which has been severely conditioned by morphological conditions of the territory and the high degree of public regulation (Costa, 2007; 2012a; Costa e Lopes, 2012a). The high demanding and strong regulation conditionings, both for the intervention on built environment, changes in typologies and the intervention in public spaces, in parallel with the ancient morphological features of the area, have facilitated until now a gentrification process much more "bohemian" "creative" class oriented than other areas of the city, where this process is much more capital and income oriented. However there are visible effects of these gentrification processes since the 80's, changing population, economic and cultural activities and even material space (in a few "gated communities" gentrification situations"). The pressure is now rising, with the symbolic mainstream of the area, both in residential market, commercial spaces market and touristic market. The new planning instruments under discussion ("Plano de Pormenor", cf. CML, 2012) are being quite polemic as they admit a wider compromise in some demarked areas with nightlife activities and make easy in the area, for instance, some kind of touristic investment such as hostels, in the area.

Concerning the conflicts directly related to externalities, four main domains can be identified:

- Infrastructure congestion - mostly traffic and parking problems, associated to the high pressure of external users into the territorial system;

- Graffiti, public art and information profusion on the streets - mostly expressed, formally and informally, in public space, but affecting private property; and affecting very distinctly the artistic/creative sensibility (and de-codifying mechanisms) of a very heterogeneous population;

- Nightlife, noise and other negative externalities - associated to cultural and creative activities in public space, but mostly to socialization and conviviality, particularly at nighttime;

DINÂMIA'CET - IUL, Centro de Estudos sobre a Mudança Socioeconómica e o Território ISCTE-IUL - Av. das Forças Armadas, 1649-026 Lisboa, PORTUGAL 
- Pollution and difficulties with collecting systems and sanitary conditions - affected by the particular morphologic conditions of the area, which requires specific collecting mechanisms, and specially the consequences of the pressure over public spaces, particularly associated to nighttime conviviality.

All this scenario offers us a relation between use conflicts, gentrification processes, territorial dynamics and sustainability of the territorial system, which can be schematically perceived (in a quite simplistic form) in figure 4. On one hand, if the level of conflict decreases, as defended by many, and attempted by some public policies, the gentrification process would have better opportunities to develop: people could move easily to a neighbourhood where is easy to live, to park, where they can get lifts at homes and parking conditions, and other lifestyles and more generalist family models would be easily attracted to the area). In the long term, is arguable (Costa and Lopes, 2012a) that this would kill the creative dynamic of the quarter (with the progressive exit of artists, led by market mechanisms and their own self-exclusion), potentially compromising the diversity, heterogeneity and vitality of the area, and the sustainability of the productive system (at least) as we know it. On the other hand, the maintenance or deepening of the existing use conflicts, affecting directly sustainability and quality of life of residents and users, would maybe delay that gentrification process, with some positive impacts in the maintenance of the productive system.

Figure 4: Conflicts of use, gentrification and system's sustainability

\begin{tabular}{|c|c|c|}
\hline (-) Use Conflicts & $\rightarrow(+)$ Gentrification & $\rightarrow(-)$ Creative Dynamic \\
\hline \multicolumn{3}{|c|}{$\rightarrow(-)$ Urban Vitality? } \\
\hline \multicolumn{3}{|r|}{$\rightarrow(-)$ Sustainability? } \\
\hline$(=) /(+)$ Use Conf & $(-)$ Gentrification $\rightarrow$. & stainability? \\
\hline
\end{tabular}

Source: own elaboration.

This reasoning brings us two important questions. The first is about the scope for public action. Which will be the scope (and legitimacy) for public action, when we put the problem like that? If we have a choice between allow the system to renew itself, even if it kills creative dynamics, and to keep it, but not enhancing quality of life of those actors, which should be the driver for public action? Should we try to keep the area as a "creative quarter" or should we let it transform itself, even regenerating and getting a new life in its urban and social-economic forms, but losing the "creative" dimension of it? The second one is about the perception of the importance of conflict. Conflict is assumed as an inherent part of this neighborhood functioning, and so its dynamics and evolution must be seen as related to the continuous management of the intrinsically internal conflicts. Self-regulation mechanisms and governance structures assume in 
his perspective a crucial role when dealing with the sustainability of these systems, and can never be left unattended when we analyze these issues.

\section{THE "DOUBLE LAYER" APPROACH TO THE SUSTAINABLE INNOVATIONS IN BAIRRO ALTO}

In this work we have adopted an analytical tool that is based on the adoption of two distinct layers of analysis for the sustainable innovations in this creative district.

A first analytical layer corresponds to the analysis of a set of "sustainable innovations" (that is, in the ASLinn project framework, innovations that are assumed by the agents involved in terms of their role in promoting sustainable development), which have been developed and introduced in this quarter, during recent years, essentially with the purpose to develop quality of life of users and residents and to promote well-being, most of them related to the management of the use conflict verified in the territory.

A second analytical layer corresponds to the study of a "collective" sustainable innovation, which is linked to the collective evolution of the district and the perceptions, representations and actions that their agents have about it. Specifically, it relates to the development of a sustainable development strategy for the territory, conducted by some of the local agents and involving other in this process, aiming to understand and to deal with the dangers of overexploitation of these system, (in economic, social, cultural and also physical/material terms). The concept of "capacity of charge" of the system (analogically to ecological systems) is here the key to understand the sustainability of this productive system.

\section{1 "Layer A": The "sustainable innovation" projects - Projects for developing innovations for sustainability}

Our «Sustainable innovative » projects in the quarter (which are essentially driven by public authorities), include a set of interventions that were being developed in recent years in 4 different domains:

\section{Graffiti control / public art strategy}

This includes a set of initiatives, developed by different departments of city council in order to solve the problems associated to graffiti and informal appropriation of the walls of the neighbourhood. Some of them are oriented to a more repressive strategy (e.g., testing and developing anti-graffiti technology on wall paintings; distribution of painting kits to residents and commerce owners in order to fight daily the new paintings; reinforcement of surveillance).

DINÂMIA'CET - IUL, Centro de Estudos sobre a Mudança Socioeconómica e o Território ISCTE-IUL - Av. das Forças Armadas, 1649-026 Lisboa, PORTUGAL 
Some other are oriented to a more comprehensive and inclusive approach to street art, and were in the origin of a wider municipal program on Urban Art in the city (including the open air "Urban art gallery" creation, in one of the main entrances of Bairro Alto (Calçada da Glória), and diverse work with the artistic graffiti community to move them from the streets to more institutional spaces, with several other innovative projects on this area - e.g., glass collectors painting programs - cf. on this Costa e Lopes, 2012). Being this a complex and polemic issue (even internally to their own departments), city council managed to develop an innovative way of dealing with it, trying to manage the conflicts but assuring on the same time to promote urban art and empower community.

\section{Traffic conditioning and public spaces management}

This includes a set of initiatives developed over the last decade to order and regulate circulation and parking problems and to facilitate public space appropriation to creative and sociability activities. Combined with other solutions to facilitate mobility in the area (e.g., construction of large parking spaces in the limits, subway access, parking tariffication system in the involving area), the city council had to develop more innovative approaches to these problems, including a pilot project on the city of prohibition/conditioning of traffic circulation in part of the quarter (restricting the traffic to residents, public transport and some users), with an electronic control system. This project (pioneer in Portuguese cities) was later introduced in several other historical quarters of Lisbon. With the consequent appropriation of these public spaces by new uses, gradually other incremental innovations, in areas such as areas urban furniture, videosurveillance, and schemes for terraces licensing, e.g., were being introduced.

\section{Urban cleaning system}

This includes a diversified set of innovative procedures, organizational improvements, but also product innovations, which were developed and introduced in order to deal with the specific urban cleaning problems in this area of the city. Due to the specific morphology of the area (which inhibit the use of conventional cleaning vehicles and tools, for instance) and to the particularities of the utilization of its public space (with a massive use during nights, especially at weekends, aggravating collecting system problems and enhancing many urban hygiene problems - e.g, with glass and other litter left massively in streets all nights, or abuse of less crowded street's public space by certain users as "toilets extensions"), a need to develop innovative solutions to these problems in this part of city made city council develop and apply different measures, at diverse levels: waste collecting systems (e.g., assumption of new routines and differentiated schedules, use of specific vehicles and circuits; $\ldots$ ); hygiene specific systems

DINÂMIA'CET - IUL, Centro de Estudos sobre a Mudança Socioeconómica e o Território ISCTE-IUL - Av. das Forças Armadas, 1649-026 Lisboa, PORTUGAL 
(e.g, development and testing of new technologies - new cleaning products/materials - to apply in the daily cleaning of the urine left by some night time users on the streets); regulation (e.g., prohibition of use of glass cups in public places).

\section{Noise control and nightlife schedules management}

This includes a set of procedures that were developed in order to reduce the externalities caused by noise associated to nightlife and conviviality activities, which are one of the main sources of tension between (some) residents and the owners of these activities and its users. Despite an active policy developed by city council and local authorities toward the inhibition of new licensing of this kind of activities (for several reasons unfruitful - cf. Costa, 2003) for the last 3 decades, and the imposition of strict regulation to their functioning (imposing the use of appropriate technologies, at construction and isolation levels), the problem is far for being solved, and the tensions periodically arise, as both at the side of the users (many increasingly using the outdoor public space, at later schedules) and of the providers (some nightlife firms, but always events' organizers, including municipal ones), the excessive behaviours continue. Some incremental innovative actions develop, in the way some actors organize their activities and their own facilities (e.g., minimizing external sound impacts of their activity), and the way city council develops new projects (essentially via regulation and licensing; e,g, with a polemic night-time schedules restrictive regulation, which was hugely contested by users and had to be soon revised).

\section{2 "Layer B": A "collective sustainability strategy" - an innovative strategy for the milieu?}

Our second analytical layer corresponds to the "collective sustainability strategy" for the local productive system, particularly associated to the work at the level of the reputational field, that is, to the management of the symbolic aspects of this territory.

It relates to the (somehow informal, but articulated) management of the perceptions and representations that local agents have about the sustainability of the area and the actions they are able to take regarding it. It relates to the development of a sustainable development strategy for the territory, driven by some of the local agents, in order to deal with the dangers of overexploitation of this system, that is to manage the "charge capacity" of it, and to avoid to surpass a limit that could put in cause the (environmental, material, social, economic, cultural) functioning of all the system.

In effect, the awareness that the massification, turistification and gentrification of the quarter (and all the increase in the use conflicts that is related to them) could compromise the long term 
evolution of a resource that all of them are "exploiting" in their own activities, made some keyagents start to think more strategically the evolution of the quarter and to try to organize in a more coordinated way their action ${ }^{7}$.

Among other aspects, the management ${ }^{8}$ of the reputation of the area (as creative area, as nightlife center, but also as "daytime" creative center - cf Grey Group, 2011) is one of the concerns of the strategy that is being developed in recent years, conducted by ACBA (commerce association of Bairro Alto, with a significant participation of nightlife and restaurant agents, besides traditional commercial activity).

Drawing upon the informal awareness of this facts and challenges by many local actors, ACBA (with the collaboration of several local public authorities and other local agents, in the cultural, economic and social intervention areas) have mobilized a wide set of agents around some discussion groups and some events all through the year, but especially around the commemoration of the Bairro Alto day (effectively, Bairro Alto week, with an extension of commemorative events, around the $15^{\text {th }}$ December, trying to mobilize, connect and cross fertilize actions amongst participants and promote the area's image - a changing image towards its exterior).

Based on volunteer participative mechanisms, and a quite informal structure and activities plan, these activities have been trying to reach the multiple layers (in each diversified segment of users, of residents, of activities) that compose the district, and make them aware of each other, able to communicate, cooperate and interact, and build collective learning mechanisms, at the same time that aim to reduce conflict and manage tensions, around common projects. The involvement of diversified interests (bar owners, NGO's, commercial activities, schools, residents associations, academics, communication agencies, public authorities concerned with multiple objectives, from culture to urban planning or social inclusion, etc.), it's a way of thinking and building collectively a strategy that could be a key-factor to enhance sustainability. The symbolic aspects are crucial here, as the collective image of the area and of their evolution, challenges and objectives is reinvented in this process, and it is a fundamental factor for the effective sustainability of the territorial system.

\footnotetext{
${ }^{7}$ The de-centralized governance of this system, tending to self-organization, has been one of the most permanent features of it, being the action of public authorities complementary but not structural in its functioning (cf Costa, 2003, 2007).

${ }^{8}$ But not the "artificial" (re)creation...
} 


\subsection{Methodological aspects}

The research conducted in this case study draws upon previous work made before on this neighborhood by the author, as stated before: on one hand the work conducted in the framework of the GREMI6 research program (Costa, 2003, 2004), and on the other hand the analysis of this case study as one of the 10 cases analyzed in the scope of CREATCITY project, enquiring the creative dynamics and their regulation forms in 3 cities - Lisboa, Barcelona and São Paulo (Costa and Lopes, 2012, 2012a; Costa 2012a). Some years later, and with other problems arising, it was considered that the ASLInn approach on sustainability would be an interesting way to revisit Bairro Alto issues and to understand the challenges to the sustainability that are verified on an urban cultural district, as well as the questions related to all the conflicts that mark a situation of this kind. So, in the context of this case study, departing from common ASLInn framework of analysis, we have based our empirical observation of this specific quarter in a diversity of methodological procedures, which included:

- Desk research / bibliographical compilation and analysis of secondary sources;

- Participation in panel sessions with stakeholders (and participant observation) ${ }^{9}$;

- Individual interviews with some key stakeholders; collective public debates;

- Analysis of policy making instruments and presentations of specific stakeholders strategies (local commerce association; local policymakers,...);

- Image recollection (photographic approach to the quarter) and content analysis;

- Socio-ethnographic work (conducted by students involved in a parallel research project in the area) which allowed information recollection from diversified sources (and formats) their discussion and analysis, and the organization of a public exhibition and debates;

In this framework, besides the interviews with the agents, common to ASLInn project approach, we would like to highlight two main specificities: On one hand, the direct involvement in several discussions arenas of local community, including the initiatives organized by ACBA and municipality which are documented in this work. It was of the utmost importance the presence in those focus/discussion groups, in several debate sessions (more academic oriented; more local agents oriented) or even a more direct participant observation in the quarters daily life. On the other hand, the opportunity to develop in parallel (and with some synergies) two other small projects developed in the quarter (the project "Bairros como nós", with photographic approach to several creative quarters; and the project "Bairro Alto dynamics through History", developed

\footnotetext{
${ }^{9}$ The author acknowledges here the collaboration of all the participants and local actors in the (open and closed) discussion groups, debates and interviews realized in the scope of this work. 
with a set of students of the ISCTE-IUL's Master degree in Architecture ${ }^{10}$, exploring diverse sources of information on the district evolution). Both of these projects, and the debates that were possible to develop in association with each of them, were extremely useful to deepen the research knowledge on the area, but also to have a floor to discussion and interaction with the local community which was very fruitful to the aims of this specific research).

\section{THE "SUSTAINABLE INNOVATIVE" PROJECTS ("LAYER A")}

\subsection{Sustainability and sustainable innovation}

In this first layer of analysis (Layer A), the "sustainable innovative projects" in the quarter, are related to the innovative products and processes introduced in the 4 fields that were mentioned above: (i) the graffiti control and the development of a public art strategy by local authorities; (ii) the traffic conditioning and public spaces management; (iii) the urban cleaning (waste collecting systems; hygiene specific systems); and (iv) the noise control mechanisms and nightlife schedules management.

These "sustainable innovations" are assumed by the local actors as such, ultimately because they provide well-being and quality of life to residents and users ("quality of space" and "quality of life and of social practices". But they are also assumed as such because, more indirectly, they contribute to reduce use conflicts (between different users of the area) and to improve also in this way quality of life and enhance livability and long term system sustainability $^{11}$

When referring to these innovations, the objectives that are essentially aimed in their discourses are mostly of an environmental nature (increase in urban quality of life, cleanliness, noise reduction...) and social nature (reduction of use-conflicts), much more immediately than economic-based ones.

This is translated in the sensation that social and technological innovations must be used together in order to achieve this "sustainability", in a field where the main driving forces to those dynamics are the huge use conflicts felt in the territory (e.g. between users/residents; traditional/new residents; traditional/new commerce; night/day users;...) and the need to solve

\footnotetext{
10 The author acknowledges the collaboration and enthusiastic participation of all the students involved, as well as the precious collaboration of Ricardo Lopes, co-author of the first of these projects.

${ }^{11}$ However, this is an arguable aspect. As previous work has demonstrated (Costa et al, 2012a), use conflicts also play a key-role in the system sustainability (e.g. via delaying gentrification), and some degree of conflict may be even essential to the continuity of this area as cultural and creative system.
} 
(or at least manage...) them. Social pressure forces the development of new institutional solutions with "innovative" solutions.

"Sustainability" rhetoric is used in this case mostly in an environmental/ecological perspective (the idea of promoting quality of living for users - e.g. less traffic, pollution, "noise", wallpaintings, public hygiene,...). It implies effectively a true sustainable action towards the solving of these problems (or at least it aims to, although not fully efficiently in some cases). This effective involvement of local actors in these fields, going in general far further than just rhetoric, does not avoid, in some specific situation a certain political instrumentalization of the discourse (e.g., in the graffiti case), which is clearly reflected in the symbolic sphere. The "sustainability" and "quality of life" discourse is inclusively clearly used as instrument of domination in the public sphere appropriation, for instance, in graffiti and public artistic intervention case (cf, Costa and Lopes, 2012).

\subsection{The context for the innovation}

More than a market push, a new standard or regulation driver, or even an answer to new forms of consumption or lifestyles, we can say that in these case these innovations result essentially from social pressure (resulting from the visible social conflicts and their environmental impacts in quality of life), which forces the need for (innovative, specific, locally-based) policy actions to solve these problems.

The ideas that are beneath these innovations emerge (or are conducted) essentially at municipal level (policy-based institutional local level, which is different - wider - from the quarter scale), by a diversity of sectoral departments, although in collaboration with some external actors/gatekeepers in some cases (e.g. involving specific firms in the cleaning programs, involving specific members of graffiti community and gatekeepers in urban art gallery, etc.).

They do not represent in general big breakthroughs, but mostly just small ruptures (or improvements) regarding the existent practices (except, may be the graffiti /art urban policy that is more ambitious in its innovative scope and more challenging to behaviors.

Some of them are inspired in external experiences and analysis of international best practices (e.g traffic conditioning, some public art galleries projects,...); some are more site-specific, involving local actors and gatekeepers in their formulation and execution (some graffiti/urban art projects, street cleaning technologies,...).

Considering their objectives and contexts of implementation, the effects expected from these interventions are essentially related to the improvements in the permanent use-conflicts

DINÂMIA'CET - IUL, Centro de Estudos sobre a Mudança Socioeconómica e o Território ISCTE-IUL - Av. das Forças Armadas, 1649-026 Lisboa, PORTUGAL 
management (and governance forms of the territorial system) that they consent and to the increase of quality of life and well-being of local population (both its users and residents).

\subsection{The innovation process}

The main focus in these various projects was public space management, which was subject to intervention by a diversity of material and immaterial resources (technical and analytical knowledge, new products, new organizational forms, new forms of appropriation and communication of symbolic knowledge, ...), which were mostly consubstantiated in incremental innovations on processes and products.

Most of these actions are recognized and legitimized both by local and external agents, although many of them are not necessarily recognized as being developed in the scope or giving answer to such kind of thing as a "natural" or "ecological" sustainability issue.

They are generally driven by public authorities (at local scale - Municipal level or/and inframunicipal level), being in some cases more formally institutionalized or in other more informal. Some are contractualized through market, even if public supported (e.g. anti-graffiti walls cleaning technologies), other are directly provided by public action (urban art gallery implementation, waste collecting mechanisms,...) or public regulation (traffic and licensing innovative procedures), other imply the coordination and collaboration of a multiplicity of actors (e.g, adoption of wall painting kits by residents).

All this imply often strong problems of coordination between agents which have naturally multiple and diversified objectives (and rationalities) in their action, what challenges permanently the governance mechanisms in which the territorial system is based. Being the use conflicts between agents a major issue in this situation, their permanent monitoring and managing implies a collective effort towards their resolution, which implies permanent (but not always easy) negotiation amongst actors with relevance amongst these unequal power relations arenas (e.g. municipal action towards public art; or licensing; or information diffusion).

In this context, there naturally is a huge diversity of mechanisms associated to the main intermediation/certification processes that are crucial to the legitimization and social recognition of these innovations and these actions. Public authorities play here a key role (imposition of norms, regulation, certification,...), but also other spaces are fundamental to the building of reputations (in economic, cultural, social, environmental fields), with particular relevance here for the role of the traditional cultural gatekeepers (in the diverse art worlds and conviviality spaces) and to the media. Being a creative quarter (and each art world - cf. Becker, 1982) a

DINÂMIA'CET - IUL, Centro de Estudos sobre a Mudança Socioeconómica e o Território ISCTE-IUL - Av. das Forças Armadas, 1649-026 Lisboa, PORTUGAL 
complex system, with multiple layers, in terms of the multiple frameworks and dimensions for the building of reputations and for the affirmation of legitimization processes (cf. Costa, 2012), it is natural that, at multiple levels, we will have diverse and complex mechanisms of intermediation and recognition of all these actions and "sustainable innovations". For instance, if we think in the specific case of public art, and the actions towards graffiti in public space, it is evident the multiplicity of frameworks of legitimization that the actors involved had to play and combine in their action (e.g. the municipality that has to manage the tension between allowing and sanctioning the graffiters that write in private and public walls; or the graffiters that see their reputation questioned by their peers when they start to adhere to municipality program and start to paint in the walls of the Urban Art Gallery - and have to keep painting trains or other walls in order to keep their "artistic" reputation in their art world (cf. Costa and Lopes, 2012).

All projects are locally embedded (and are strongly determined by local characteristics of place), but can (and some do) be enlarged for other areas of the city. That is the example of the urban art murals, which were the kick off experience to other programs now developing in other areas of the city; or also the case of traffic conditioning system, which was later reproduced in several other historical quarters of the city.

The municipal level of intervention and regulation has a fundamental role on this, being the most significant when we think on the institutional (and also geographical) scales involved on these projects, although some of them have articulation with worldwide/global circuits (e.g, the street art programs, which have developed partnerships and collaboration with top artists at world level to those actions).

All these sustainable innovation projects have a strong embededness both in their temporal and spatial dimensions. Although their time frame is variable (all of them are being implemented in the last 10 years) they are all strictly committed to the resolution of present problems and situations, which are consequence of the long term specialization of the quarter in the cultural and creative sector, and on the conviviality and sociability functions that are intimately linked to it, which were going under a huge growing (and transformation) process in the recent years, increasing externalities, conflicts, and challenging more accurately the sustainability of the territorial system.

In this innovation processes, localization strategies were naturally related to the territoriality of this case's dynamics, which are by their own nature, naturally, territorially embedded (all the social, cultural and economic practices involved).

DINÂMIA'CET - IUL, Centro de Estudos sobre a Mudança Socioeconómica e o Território ISCTE-IUL - Av. das Forças Armadas, 1649-026 Lisboa, PORTUGAL 


\section{5. "COLLECTIVE SUSTAINABILITY STRATEGY" (LAYER B)}

\subsection{Sustainability and sustainable innovation}

In this second layer perspective, the collective strategy towards sustainable development, few of the agents of this area will have a plain conscience or a self-awareness of a collective "innovative" behavior or strategy towards the sustainability of the Local Productive System. However, some of them (commerce and residents associations, several cultural agents, communication agencies, several public departments, at local and municipal level, researchers, other local associations, aiming social, educational or cultural purposes, etc) are involved in collaborative platforms, embedded on the innovative and creative atmosphere of the local milieu, which are the basis for this. In particular commerce association (ACBA), together with some municipal departments and other agents, was mobilizing participation and developing discussion around specific groups (involved, for example, around the organization of "Day of BA" event - a week for the commemoration of the "birth" of Bairro Alto, with several cultural events around and a communication strategy associated to it - in 2011 commemorated 498 years ${ }^{12}$ ). This, for instance, has been a platform for discussion, and have given shape to several collective action initiatives (some departing from other associations, other from communication institutions - e.g. I Love Bairro Alto website -, or others cultural institutions, for example, mostly concerned with the promotion of the quarter activities, but also its "sustainable" development, and the risks and conflicts that are challenging it. Of course each of the agents involved in this movement would have their own agendas (and particular interests on this), ACBA included, but they have managed to develop a collective agenda too (more or less shared, depending on the issues), around the sustainability of the quarter, and having as action driver some specific purposes, such as the commemoration of "Bairro Alto day/week", or other aimed to the resolution or debate of specific issues in the life and evolution of the quarter.

They correspond (indirectly, not always with full self-awareness of it) to the feeling of unsustainability of the recent year's development model of the area. This includes environmental sustainability (and the notion of "charge capacity" of the system), and the sense that it is crucial to the urban "attractiveness potential" of the area to promote a development model that doesn't compromise de essential features (in cultural, economic, social, environmental terms) that are the matrix of the creative dynamics and the specific vitality of this

\footnotetext{
12 For an overview of the activities of the "Bairro Alto day" activities in 2011 and 2012, see http://diadobairroalto.blogspot.pt/.
}

DINÂMIA'CET - IUL, Centro de Estudos sobre a Mudança Socioeconómica e o Território ISCTE-IUL - Av. das Forças Armadas, 1649-026 Lisboa, PORTUGAL 
area of the city. The objective of their action is thus multidimensional, combining and crossing the frontiers of strict economic, social or environmental purposes.

Actually, we are facing here social and organizational innovation, much more than technological based innovation, which is driven essentially by social (and governance) issues: the increasing self-awareness of the problem of long-term sustainability (with massification and the increase of charging pressure onto the system) by some key local agents.

The word "sustainability" is used to talk about the long term prospects for the evolution of the quarter, and at the end to the socio-economic subsistence of the quarter (its competitive capacity), but environmental quality (and consequent symbolic repercussions) are also important factors assumed for the attractiveness of the area. As consequence, this "rhetoric of sustainability" has a concrete materialization on this collective action. Of course that, in parallel, there are also other effects, associated to this rhetoric.

Among other examples, we can refer the instrumental use of this discourse based on "sustainability" and "quality of life" enhancing protectionist behaviors by the Commerce Association or bar and nightlife owners (with strong influence on ACBA), as they defended strongly the need of a law against drinking (in glasses) in the streets (with direct results on the regulation of those activities), defending themselves against the concurrence (for them, unfair) of the convenience stores and some "ethnic" commerce that developed in the quarter in recent years. The argument against this, defending that people should only drink in plastic recipients (which bars provided to their clients in case of outside drinking) was used essentially for "sustainability reasons" (avoiding the problem of glass waste recollection and decreasing noise externalities related to outdoors drinking), but of course they obtain from the approval of this law a considerable competitive advantage in economic terms for their own personal businesses.

\subsection{The context for the innovation}

The sustainable innovation that we have in this case is essentially due to the increasing selfawareness of the dead-end that the growth model followed in last decades in the Bairro Alto district (based on massification and extensive "creative growth") will lead to. The perception that the economic development of the quarter, associated with progressing gentrification and turistification processes, and intimately related to nightlife and consumption oriented growth, will not be sustainable, and probably will develop the externalities and conflicts to an unbearable degree, make some of the main actors of the system act, and mobilize other to this "sustainable innovation". Of course, this would be also partially fueled in parallel by natural

DINÂMIA'CET - IUL, Centro de Estudos sobre a Mudança Socioeconómica e o Território ISCTE-IUL - Av. das Forças Armadas, 1649-026 Lisboa, PORTUGAL 
particular interests of some of those agents, so we can consider that we would have also some kind of market driven push in those actions.

It all started with a diffuse idea, assimilated by some key actors, which was vital for the emergence of innovation. The role of Commerce Association (ACBA - Associação de Comerciantes do Bairro Alto), and particularly the dynamism of his president was fundamental here, in the dynamization of the action, internally and externally. Aggregating and mobilizing the diverse institutions and partners involved in the operation was also a step of utmost importance, and again here the importance of some key persons (the role of individual leadership and strategic vision) was vital, in several institutions (e.g., the role of Municipal Libraries Division Manager, even outside the area, the Camões Library staff, the MySkillz inclusion project staff, some local blogs and cultural agents involved, some academic researchers,...).

This was a process that developed somehow spontaneously, based on the progressive and ongoing self-consciousness of a problem, but draws on the history of the evolution of most cultural district throughout the world. To a certain extent it is also a process that is result from the knowledge (and some discussion) of those similar experiences, and would be even fruit of some academic reflexivity, which informed this discussion.

The expected effects of this innovation on its economic, social and territorial context relate essentially with the delay in the massification and gentrification processes, the continuity and vitality of the "cultural-based" local productive system in this part of town; and, at the end, the attractiveness of (or the improvement of the capacity to retaining) "creative people" to the area.

\subsection{The innovation process}

The resources mobilized in this project are essentially centered on symbolic assets. We are dealing here mostly with incremental innovation, based on an intangible product, which is related to immaterial resources (essentially symbolic knowledge, associated to the collective image of the creative quarter), and to the relational capacity of the territorial agents (their associative capacity and their participative potential). This can be fueled by governance mechanisms able to give coherence and articulation to the diversity of expectations and ambitions of local agents, in a context in which these actions are mostly not recognized or perceived directly as innovative/sustainable by local or external actors.

Self-coordination and voluntarism are the central elements in the development of these actions, which are characterized by their openness to participation of all and their inclusiveness (e.g,

DINÂMIA'CET - IUL, Centro de Estudos sobre a Mudança Socioeconómica e o Território ISCTE-IUL - Av. das Forças Armadas, 1649-026 Lisboa, PORTUGAL 
discussion forum, participative mechanisms), although they've been until now essentially been driven by the mobilization from ACBA (and precious help, and legitimization by some municipal departments, mostly linked to cultural area), but with diverse partners in economic, cultural and social fields (including multiple public authorities, NGO's and firms).

The main intermediation processes that are crucial to the legitimization (in this case broader social recognition) of this innovation relate to their visibility in the city (that is, to the conscientiousness of the aims of the strategy by the responsible and directly involved in the quarter management). In this, the development of more de-centralized participatory mechanisms (promoting the empowerment of local agents, users and residents), the role of traditional media and cultural gatekeepers, but also the close involvement of some media partners in the project (a communication agency and some other partners are involved) are key-factors to enhance the legitimization of these "collective sustainability strategy", which goes against most of the generalized practices of local and external practices and expectations regarding this area.

By its own nature, the project is defined for this specific territory and is strictly locally embedded, although it involves a diversity of geographical and institutional scales in its functioning. It is very significant the diversity and multiplicity of scopes and scales of action of each participant (e.g. a local commerce association centered on the quarter vs art galleries with much broader hinterlands in their activity, a municipal network of libraries, or even foreign academic researchers interested in the study of the local creative system and their international comparison). New localization strategies related to this innovation are not significant, due to its strict territorial embeddedness, but the future evolution of the district (and of course the direct outcomes of these project) will be determinant for future decisions of (re)localization of most of the actors involved.

Its time frame is clearly recent, being developed essentially in the one/two last years, as the awareness of the problem and of the potential for collective action developed, and the conditions for an innovative behaviour were being established. However, it can be assumed as projected into the future, as the concerns with the sustainability of the local system that were arisen by this specific project will certainly keep seeds for the collective reflection (and also polemics) of the future of the area amongst local agents and public regulators. 


\section{REPUTATION BUILDING, GATEKEEPING AND SUSTAINABILITY OF A CREATIVE DISTRICT}

The analysis of this sustainable innovation processes in Bairro Alto creative district, in both the perspectives assumed, raise a set of issues that are particular important for the study of innovative milieus, but also for the specific case of creative/cultural led territorial development cases.

We had opportunity elsewhere to discuss the importance of gatekeeping and reputation building mechanisms to the structuration, liveliness and vitality of creative milieus (Costa, 2012). These mechanisms are of utmost relevance, and their interest can be analyzed at two distinct levels, which are particularly interesting for us.

On one hand, they are fundamental to the structuration and affirmation of the creative milieu itself. They are an intrinsic part of the symbolic sphere associated to the territorial production/consumption system, and, so, all the representation on the territory (by the own actors or the ones outside it) are an important part on the dynamics and the evolution that can take part on it. In this sense, all the issues concerning the image and the symbolic (co)production of territories are in cause here, and they are important in any territorial milieu (although clearly amplified in a situation of a territorial system based on creative or cultural activities, where the symbolic and aesthetic component has an increased dominance in value creation and in differentiation). All the issues related to the discussion around the authenticity of place and the constructions that are made about it (via self and hetero-representations), are particularly relevant here, and that would be most interesting and complex when dealing with more "intangible" innovation processes.

On the other hand, they are fundamental to the own functioning of the cultural activities and the art worlds that are in the centre of these creative milieus. In effects, cultural production and cultural consumption are conditioned and structured by a variety of mediation processes and mechanisms in which the legitimization of reputations are made (cf. Becker, 1982; Di Maggio, 1987; Caves, 2002; Costa, 2012). These gatekeeping processes have strong territorialization mechanisms, even in the scope of (apparently globalized or even de-territorialized) multi-scale and multi-agents processes. Creative districts have a crucial role on this (even sometimes with production and consumption exiting those areas), and innovative milieus based on creative/cultural activities must be undoubtedly understood with these mechanisms in mind.

But when we join the dimension of "sustainable innovation" to all this, the degree of complexification increases, and new dimensions must be taken into account. The importance of

DINÂMIA'CET - IUL, Centro de Estudos sobre a Mudança Socioeconómica e o Território ISCTE-IUL - Av. das Forças Armadas, 1649-026 Lisboa, PORTUGAL 
reputation building and legitimization processes maintains all its pertinence and relevance for the structuring of the territorial system. But another layer of discussion must be added to this debate.

In effect, when we talk about reputation in these creative systems (or in the innovation processes that occur in them), we are talking here of three different levels of reputation:

First, we can be discussing the legitimization of the cultural/activity itself. We are discussing in this case the reputation of the actor that takes part of this productive system (of the artist, of his work, of the promoter, of the facility where activity takes place, etc. ${ }^{13}$ ). We are discussing its reputation as "creative".

Second, we can be discussing the legitimization of the quarter/district itself. We are talking in this case of the reputation of the territory and its image as "creative quarter"

Third, we can be discussing the legitimization of that creative activity or creative territory in terms of its sustainability. In this case we are talking about its reputation concerning the sustainability issues, and we are trying to assess if these creative quarter, for instance, has the symbolic attributes, and the image, that allow it to be reputed as a "sustainable creative quarter". When we talk about our sustainable innovations in the Bairro Alto creative quarter, we are naturally mixing and crossing the representations about it (and the gatekeeping respective processes) in all these 3 different dimensions. Moreover, we are overlaying in each of them multiple grids of legitimization in which each agent assess and build representations and reputations, and many of them are non-coincident or even conflicting. For instance, when a graffiter collaborates in the institutionalized "urban art gallery" instead of tagging other street's walls, he is questioning is reputation in its own art world as artist, tough being legitimized (regarding sustainability, but also regarding his artistic value) by other persons outside its original art world. When ACBA joins an operation questioning the massification of the quarter, even against some of its short term economic interests, it gains reputation and legitimization in social and environmental terms, which can be capitalized in long run economic revenue.

Naturally, the very diverse interests and motivations of the multiple agents, in these various fields are in the roots of the diverse use conflicts verified, but are also translated in varied attitudes and levels of reputation attributed to the diverse "sustainable innovations" analyzed (be it the attitudes towards graffiti, towards nightlife, or the conception of a sustainable creative quarter...).

\footnotetext{
${ }^{13}$ And all of these are strictly inter-related - cf. Costa, 2012 on this.

DINÂMIA'CET - IUL, Centro de Estudos sobre a Mudança Socioeconómica e o Território ISCTE-IUL - Av. das Forças Armadas, 1649-026 Lisboa, PORTUGAL 
All this have implications concerning the diverse hypothesis that were launched in the scope of this collective ASLInn research, and to the innovative milieu concept, as we argue in the next section. For now we just would like to highlight two ideas associated to two of those hypotheses, broadly confirmed by this cases' analysis: the importance of symbolic management to the promotion of a place competiveness; and the consequent need for more complex, coordination oriented, public policies.

In effect, in a creative quarter such this one, they are evident the multidimensional forms of anchoring of this territorial system, at diverse scales, and at parallel dimension (economic, cultural, social, environmental), which refer us to a multitude of parallel gatekeeping processes. The multiplicity of rationalities inherent to this system's actors (including naturally considerable "extra-economic" motivations) is clear and demands the awareness that their actions and their reputation building processes are done in this complex framework. When sustainability is one of the drivers for their action all this gains plus relevance. With this framework, the mobilization of symbolic milieu assets (in particular the "sustainable" future and the quality of living in the quarter) is a key factor to assume "sustainable innovations", as clear in most of the interventions studied in this case. Naturally, all this implies new challenges to public action, on one hand facing more complex multilocal/multiscalar governance forms, and on the other hand defending more diversified "public interests" (e.g. the quality of life of residents who want to rest vs the quality of life of users that want to consume culture and socialize), into the need to think and prepare more holistic, comprehensive and integrated territorial-based public policies.

\section{CONCLUDING NOTE: CHALLENGING THE INNOVATIVE MILIEU?}

This paper aimed to shed some light in the processes conducting to sustainable innovation on a creative district that is being challenged by the over-charge of its own competitive resources and by the pressures to gentrification and socio-economic and cultural massification. The strategies developed by public authorities to manage many of the multiple use conflicts that threaten the area (through the diverse sustainable innovations" analyzed on layer A) or by the collective of local agents in order to change the image of the quarter (through the collective strategy analyzed on layer B) show us two different ways to introduce innovative products, processes and organizations in these system towards the objective of promote sustainability.

But they give us also some hints that can be used to (re)think the innovative milieu concept and the way it can be useful to understand "sustainable innovations" on a broader scope. If we think

DINÂMIA'CET - IUL, Centro de Estudos sobre a Mudança Socioeconómica e o Território ISCTE-IUL - Av. das Forças Armadas, 1649-026 Lisboa, PORTUGAL 
in each of the layers inherent to a milieu (the territorial productive system, the governance system, and the representation system) these challenges become more evident.

Considering the territorial production/consumption system, the first notion that becomes relevant is that the territorialization, the embededness, the link to territory is still a determinant factor, even economic, social or symbolic effects of it are spread a lot vastly than its direct territorial implementation. The system is intrinsically linked to the specific territorial characteristics, resources and local actors, as well as to their specific problems, challenges, and constraints. The territorial anchorage is made in diverse ways, articulating these endogenous characteristics with global dynamics and exogenous resources, both at economic and symbolic levels (e.g. knowledge flows, reputation building and legitimization circuits).

The innovative component is fundamental although maybe less dependent from technical developments and more oriented to institutional and organizational issues. The sustainability arises both from technical and institutional factors, that emerge and contribute to the resolution of the existing problems or seizing new opportunities identified by the productive system. The driver for this "sustainable innovation" may be oriented to promote better solutions to environmental problems (developing new products, providing better efficiency in the use of resources, reducing the effects of negative externalities,...) or avoiding the overexploitation of resources.

As a consequence, its relevance (and its perception) crosses frequently the conventional borders between the dominance of the "economic", "environmental" or social" perspectives on sustainability, which drive the action and behaviors of the multiple members of the system, that naturally have diverse motivations, expectations (and conceptions) on "sustainability".

One fundamental aspect that is distinctive in these "sustainable innovations" from precedent analysis of other innovative systems is the importance of the integration between production (providers) and consumption (users) which are increasingly imbricated. Not only this intersection is fundamental for the structuration of the system (e.g, walls cleaning or collecting systems) but it is also fundamental to the development of innovation. It doesn't emanate necessarily from one of the sides, but it needs often coordination between the interests in both sides, being this articulation fundamental from the development of the innovative solution. If in other cases this would be essentially made by the market, institutional arrangements, regulation or strategic policy frameworks, in this case study is essentially fruit of social, political and environmental pressure that confronts local agents with the need to collaborate to solve their problems together.

DINÂMIA'CET - IUL, Centro de Estudos sobre a Mudança Socioeconómica e o Território ISCTE-IUL - Av. das Forças Armadas, 1649-026 Lisboa, PORTUGAL 
This production/consumption system, strongly territorially embedded, aggregate the specific milieu conditions that are fundamental to develop those concrete innovations. The multiple types of returns (or expected returns) that the investment on these innovation processes can bring, in the monetary sphere, but also in terms of social recognition, legitimization, quality of life or environmental satisfaction, for example, are the driver to articulate a variety of diverse actors (which are moving inside, inwards and outwards that specific territory) around a specific project (for the city, for the sector, for the business firm, for the community, for the global common future) that configures in this specific production-consumption system, one of the multiple potential meanings of "sustainability" and one of the potential fields for "sustainable innovations".

Thus, if we look from the perspective of another fundamental component of an innovative milieu, the governance system, its importance is fully confirmed, and it assumes as a key-role in the development of the "sustainable innovations". The institutional arrangements and the formal and informal mechanisms of interrelations amongst the actors that configure the basis of governance of the system are also fundamental for the development of the sustainable innovations. When we talk about sustainable development, as it is expressed above, we are dealing with an integration around a project that is a specific concretization (between the multiple possibilities) of "sustainable" for each actor involved. In the presence of such a variety of motivations, interests and even rationales for action (and complex conflict fields), the governance mechanisms of the system are the glue that allow the articulation of agents around this concrete projects, almost all of them combining multiple public and private interests, and bringing together several types of collective (the city, the quarter, the sector, the collectivity) and individual motivations.

Finally, this case allows challenging further the milieu notion considering also the representations system and the symbolic sphere. Although the external and internal representation systems already represented an important role in the dynamics of a traditional innovative milieu, in cases like this, associated to the sustainable development, the sphere of the symbolic seems to represent an increased importance. In effect, the importance of symbolic is important not only as identification with the territorial system and its "atmosphere", as part of the construction of the "sense of belonging" to the milieu, but can be also fundamental in the creation of value and in the innovative differentiation of the system. The affirmation of this value is not made in this case (contrary to other case studies in this project) essentially by the innovative valorization on market or its demonstrative effect to gather funding for future implementation, but is made around the notion of long term gains (and "value" creation) at a

DINÂMIA'CET - IUL, Centro de Estudos sobre a Mudança Socioeconómica e o Território ISCTE-IUL - Av. das Forças Armadas, 1649-026 Lisboa, PORTUGAL 
Bairro Alto revisited:

Reputation and symbolic assets as drivers for sustainable innovation in the city

diversity of levels (economic, social, cultural, environmental) for the multiple agents involved in these actions. The construction of value (economic value, social/reputational value, environmental value, cultural value) must be understood considering the multiplicity of scales of legitimization in which this value is perceived, and the multiplicity of strategies that actors develop to achieve their valuation in those scales. The value created (in efficiency of the system functioning, in reduction of conflicts, in well being generated, in long or short run market profits,...) is strongly determined by the symbolic content associated to "sustainability" itself and, as such, this "sustainable innovations" contribute to challenge to new limits the innovative milieu notion. 


\section{REFERENCES}

Asheim, B; R. Boschma and P. Cooke (2011), "Constructing Regional Advantage: Platform Policies Based on Related Variety and Differentiated Knowledge Bases", Regional Studies, Vol.45.7, pp. 893-904, July 2011.

Balula, L. (2010), "Espaço público e criatividade urbana: A dinâmica dos lugares em três bairros culturais", Cidades, Comunidades e Territórios, n²0/21, Dezembro 2010, pp. 43-58.

Becker, H. S. (1982), Art Worlds, Berkeley - Los Angeles - London: University of California Press.

Camagni, R., D. Maillat e A. Matteaccioli (Eds.) (2004) Ressources naturelles et culturelles, milieux et développement local, Neuchâtel: EDES.

Carita, H. (1994), Bairro Alto. Tipologias e Modos Arquitectónicos. Lisboa: CML.

Caves, R. (2002), Creative Industries: Contracts between Art and Commerce. Cambridge /London: Harvard University Press.

CML (2010), Plano Director Municipal de Lisboa, Regulamento da proposta de Plano, Julho 2010, Lisboa: Câmara Municipal de Lisboa.

CML (2012), Propostas de alteração dos Planos de Urbanização dos núcleos históricos. Lisboa: Câmara Municipal de Lisboa.

Cooke, P. and L. Lazzeretti (org.) (2007), Creative cities, cultural clusters and local development. Cheltenham: Edward Elgar.

Costa, P. (2003), Efeitos de meio e desenvolvimento sustentável num bairro cultural: a zona "Bairro Alto-Chiado - Relatório Final, CIRIUS/ISEG/UTL e CML, Lisboa.

Costa, P. (2004), "Milieu effects and sustainable development in a cultural quarter: The Bairro Alto - Chiado area in Lisbon", in Camagni, R., D. Maillat e A. Matteaccioli (Eds.) Ressources naturelles et culturelles, milieux et développement local, Neuchâtel: EDES, pp. 157-193.

DINÂMIA'CET - IUL, Centro de Estudos sobre a Mudança Socioeconómica e o Território ISCTE-IUL - Av. das Forças Armadas, 1649-026 Lisboa, PORTUGAL 
Costa, P. (2007), A cultura em Lisboa: competitividade e desenvolvimento territorial, Lisboa: Imprensa de Ciências Sociais.

Costa, P. (2008), “Bairro Alto: um bairro cultural ameaçado?”, Revista Autor, ano VIII, nº7, Julho 2008.

Costa, P. (2012), "Gatekeeping processes, reputation building and creative milieus: evidence from case studies in Lisboa, Barcelona and São Paulo", in Lazzeretti, L (Ed.), Creative industries and innovation in Europe: Concepts, measures and comparatives case studies", New York: Routledge, pp. 286-306.

Costa, P. (org.) (2012a, forthcoming), Criatividade e Vitalidade Urbana. Lisboa, Barcelona e São Paulo, em publicação.

Costa, P., Lopes, R. (2011), "Padrões locativos intrametropolitanos do cluster da cultura: a territorialidade das actividades culturais em Lisboa, Barcelona e São Paulo", REDIGE - Revista de Design, Inovação e Gestão Estratégica, Vol. 2, n. 02, 2011, pp. 196-244.

Costa, P., Lopes, R. (2012), "Is street art institutionalizable? The case of graffiti in Lisbon city center", Paper presented to the Annual Meeting of the Association of American Geographers, New York, 22-26 February 2012.

Costa, P, Lopes, R, (2012a), "Urban design, public space and the dynamics of creative milieus: a photographic approach to Bairro Alto (Lisboa), Gracia (Barcelona) and Vila Madalena (São Paulo)”, Dinâmia Working Paper, 2012/18, Lisboa: DINÂMIA'CET - IUL.

Costa, P; M. Magalhães, B. Vasconcelos, e G. Sugahara (2008), On 'Creative Cities' governance models: a comparative approach. The Service Industries Journal , Vol. 28, $\mathrm{n}^{\circ} 3-4$, April-May 2008, pp. 393-413.

Dias, S. (2010), "Um percurso histórico por 3 bairros criativos: a identidade e a formação morfológica urbana", Dinamia'CET Working Paper, WP 11/10, DINÂMIA-CET.

DiMaggio, P. (1987), "Classification in art", American Sociological Review, 1987, vol. 52, August, pp. 440-455.

DINÂMIA'CET - IUL, Centro de Estudos sobre a Mudança Socioeconómica e o Território ISCTE-IUL - Av. das Forças Armadas, 1649-026 Lisboa, PORTUGAL 
Evans, G. (2009) Creative Cities, Creative Spaces and Urban Policy, Urban Studies, 46(5-6): $1003-40$.

Flew, T. and Cunningham, S. (2010) 'Creative industries after the first decade of debate', The Information Society, 26(2): 113-23.

Grey Group (2011), Bairro Alto - Estratégia de comunicação. Relatório 30 Junho 2011, Lisboa: Grey Group.

Jeannerat, H. and O. Crevoisier, "Cultural Activities in territorial development: The case of cultural and creative enterprises in the Swiss watchmaking industry", in Lazzeretti, L (Ed.), Creative industries and innovation in Europe: Concepts, measures and comparatives case studies", New York: Routledge, pp.232-250.

Kebir, L., Costa, P; Crevoisier, O., and Peyrache-Gadeau, V. (2011) Description du Project "Ancrage, durabilité, localization de l'inovation: vers des nouvelles forms territoriales des activités?", mimeo.

Lazzeretti, L (Ed.), (2012) Creative industries and innovation in Europe: Concepts, measures and comparatives case studies", New York: Routledge.

Peyrache-Gadeau, V; O. Crevoisier, L. Kebir e P. Costa (avec collaboration de A. Ba) (2010), Ancrage et durabilité: Pierres angulaires de l'analyse des dynamiques territoriales, Rapport Finale, Recherche menée pour le PUCA, Ministère de l'Ecologie, du Development Durable et de la Mer. CNRS - EDYTEM - GREMI.

Moulaert, F and Sekia, F. (2003), "Territorial Innovation Models: A Critical Survey”, Regional Studies, 37.3, pp. 289-302.

O'Connor, J., Wynne, D. (ed.)., 1996. From the Margins to the Centre: Cultural production and consumption in the post-industrial city. Aldershot: Arena.

Scott, A. J., 2000. The Cultural Economy of Cities. New Delhi, London- Thousand Oaks: Sage

DINÂMIA'CET - IUL, Centro de Estudos sobre a Mudança Socioeconómica e o Território ISCTE-IUL - Av. das Forças Armadas, 1649-026 Lisboa, PORTUGAL 